\title{
Neoliberal Düzende Panoptik Denetim Tahayyülü: The Platform Filmi ve Düşündürdükleri
}

\author{
Hüseyin Köse \\ Prof. Dr. \\ Atatürk Üniversitesi İletişim Fakültesi Gazetecilik Bölümü \\ huseyink180@yahoo.com \\ ORCID ID: 0000-0001-5697-9009
}

Tahir Bingöl

Doktora öğrencisi

Atatürk Üniversitesi Sosyal Bilimler Enstitüsü Gazetecilik Ana Bilim Dalı

tahir413@hotmail.com

ORCID ID: 0000-0001-7296-179X

\begin{abstract}
The Envisagament of Panoptic Control in the Neoliberal Order: The Movie The Platform and Afterthoughts

The movie titled The Platform contains many metaphors and symbols that requires reflection about today's unequal neoliberal order by taking into account the panoptic model of control. The prison model envisioned in the movie is almost like a concrete metaphor for a world shaped according to the neoliberal economic system. In the place of control with a total of 333 floors, those on the upper floors greedily feed themselves, while those below naturally starve. The real power that manages and controls this ruthless mechanism is invisible to the eye. The study aims to examine the aforementioned movie with regard to the neoliberal living order in terms of its results reinforced by panoptic control and in this respect, it is significant in terms of establishing a direct relationship between the concepts of neoliberalism and surveillance. In the study, mainly semiotic method and in addition, sociological analysis, a frequently applied method in the field of film analysis were used and as a result the destructive effects that emerge at the point where the dominant neoliberal order meets the disciplinary desire of the power were found out.
\end{abstract}

keywords: The Platform, movie, panoptic control, neoliberal order. 


\section{Résumé}

\section{L'envisage du contrôle panoptique dans l'ordre néolibéral : le film The Platform et des réflexions après coup}

Le film intitulé The Platform contient de nombreuses métaphores et symboles qui nécessitent une réflexion sur l'ordre néolibéral inégalitaire d'aujourd'hui en prenant en compte le modèle panoptique de contrôle. Le modèle carcéral envisagé dans le film est presque comme une métaphore concrète d'un monde façonné selon le système économique néolibéral. Dans le lieu de contrôle à 333 étages, ceux qui se trouvent dans les étages supérieurs se nourrissent avidement, tandis que ceux qui se trouvent dans les étages d'en bas meurent naturellement de faim. Le vrai pouvoir qui gère et contrôle ce mécanisme impitoyable est invisible à l'œil. L'étude vise à examiner le film susmentionné en ce qui concerne l'ordre vivant néolibéral en matière de ses résultats renforcés par le contrôle panoptique et à cet égard, il est significatif en matière d'établissements d'une relation directe entre les concepts de néolibéralisme et de surveillance. Dans l'étude, principalement la méthode sémiotique et en plus, l'analyse sociologique, une méthode fréquemment appliquée dans le domaine de l'analyse cinématographique ont été utilisées et par conséquent les effets destructeurs qui émergent au point où l'ordre néolibéral dominant rencontre le désir disciplinaire du pouvoir ont été découvert.

mots-clés: The Platform, le film, le contrôle panoptique, I'ordre néolibéral.

\section{Öz}

The Platform filmi günümüz eşitsizlikçi neoliberal paylaşım düzenini panoptik denetim biçimiyle birlikte düşünmeyi gerektiren birçok metafor ve sembol içermektedir. Filmde tahayyül edilen tutukevi modeli, adeta neoliberal ekonomik sisteme göre biçimlenmiş bir dünyanın somut eğretilemesi gibidir. Toplam 333 katın bulunduğu denetim mekanında, üst kattakiler büyük bir açgözlülükle beslenebilirken alttakiler doğal olarak aç kalmaktadırlar. Bu acımasız düzeneği yönetip denetleyen asıl güçse göze görünmemektedir. Çalışma, söz konusu filmi neoliberal yaşama düzenini panoptik denetimle tahkim edilmiş sonuçları açısından irdelemeyi amaçlamaktadır ve bu bakımdan, neoliberalizm ve gözetim kavramları arasında dolaysız bir ilişki kurması bakımından önemlidir. Çalışmada ă̆ırıklı olarak göstergebilimsel yönteme ilaveten film çözümlemesi alanında sıklıkla başvurulan sosyolojik analiz türü kullanılmış ve sonuç olarak, hâkim neoliberal düzenin iktidarın disipline edici arzusuyla birleştiği noktada ortaya çıkan yıkıcı etkiler saptanmıştır.

anahtar kelimeler: The Platform, film, panoptik denetim, neoliberal düzen. 


\section{“Insan aç kalmayagörsün, inançlarını bile yer." Albert Camus}

\section{Giriş}

Iktidarın kontrol etme arzusu bugüne dek farklı biçimlerde tezahür etmiştir. Genellikle iktidar her zaman gözetleyen güçtür ve bir süper gözetleyen olarak ilk iddiası da muhtemelen güvenliktir. Zira devlet erkiyle tahkim edilerek kamusal alanı gözetleyen kameraların başat amacı toplumsal düzen içinde kaos ve anarşi ortamına mahal vermemektir. Haliyle güvenlik temelli gözetim, beraberinde denetim ve disiplini getirir. Söz konusu disiplinin hedefi sadece toplumsal bütün değil, bizatihi onu oluşturan her bir parçanın, tek tek üyelerinin de bedenleridir. Günümüzde bedenlerin disipline edilmesi Jeremy Bentham'ın artık klasikleşmiş hapishane modeli ve gözetleme kuleleri mimarisinden hayli farklılaşmıştır. Yeni iletişim ağları, dijitalleşme ve bilgi teknolojilerinde yaşanan radikal düzeydeki değişimler modern gözetim pratiklerine yeni ve sofistike boyutlar katmıştır. Artık gözetleme kuleleri -Lyon'un deyimiyle "konteyner'ları"- muğlaklaşmış, birbiriyle iç içe girerek, deyim yerindeyse, "mühürlenmiştir" (Lyon, 2006, s.75). Bu yeni gözetim teknolojileri arasında; üç boyutlu kameralar, insansı hava araçları, veri gözetimine olanak sağlayan genetik teknolojisi, vb. sıralanabilir. Gelinen noktada gözetimin tam da eşiğinde olduğumuz dijital çağın gereklerine uygun formatta şekillendiği söylenebilir.

Konu ile ilgili alanyazın tarandığında gözetim kavramının yeni teknolojiler, mahremiyet olgusu ve iktidar ekseninde incelendiği görülmektedir. Nitekim çaıışmalarda gözetimin geçirdiği dönüşüme odaklanılmıştır. Söz konusu çalışmalardan birkaçı şöyledir: Oğuzhan Özgür Güven (2012) "Gözetimin Neoliberal Risk Bağlamında Dönüşümü ve MOBESE Kameraları" adlı neoliberal sistemde gözetim ve denetimi irdeleyen doktora çalışmasında, iktidar aracı olarak gözetimin geçirdiği dönüşümü mobese kameraları ekseninde ele almakta ve sonuç olarak katılımcıların mobeseleri güvenlik açısından olumlu karşıladıklarını ve kamera eksikliği yönünde ise talepkar bir uslüba sahip olduklarını saptamaktadır. Selin Bitirim Okmeydan (2017) "Postmodern Kültürde Gözetim Toplumunun Dönüşümü: 'Panoptikon'dan 'Sinoptikon' ve 'Omniptikon'a" adlı makalesinde ise modernizm ve postmodernizm ekseninde panoptikon, sinoptikon, omniptikon kavramlarına odaklanmaktadır. Yazar, gözetimin postmodernizmin dinamikleriyle paralel geliştiğini ve panoptik gözetimde iktidarın görünür olmadan bilinmesine rağmen; omniptikon ve sinoptikonda iktidarın görünürlüğünün tamamen silikleşerek inşa edildiği sonucuna varmaktadır. Son olarak Dilar Diken Yücel (2015) "Sinema Filmlerinde Gözetim ve İktidar İlişkilerinin İnşası" adlı makale çalışmasında, gözetimin kim tarafından, hangi amaçlar için yapıldığını ve gözetim sonucu ortaya çıkan mahremiyet sorununu sinema filmleri üzerinden tartışmaktadır. Yazar, gözetimin iktidarın sürekliliğini sağlamada kilit bir öneme sahip olduğu ve mahremiyet sınırlarının ihlal edildiği sonucuna ulaşmaktadır. Bu çalışma, literatürdeki benzer çalışmalardan farklı olarak, The Platform filmi üzerinden neoliberal yaşama düzenini nekropolitik 
bir düşünce ve panoptik denetimle tahkim edilmiş yıkıcı sonuçları açısından irdelemeyi amaçlamaktadır. Çalışmada ilk olarak toplum, iktidar ve gözetim kavramları arasındaki ilişkiye odaklanılıp, gözetim olgusunun mahiyeti iktidar mikrofiziği ekseninde irdelenmektedir. Çalışmanın analitik kısmında ise, neoliberal dünya düzeni ve panoptik denetimci pratiklerin ürettiği insanlık dışı sonuçlar söz konusu filme ilişkin göstergesel ve sosyolojik referanslar eşliğinde irdelenmektedir.

\section{Yöntem}

Çalışmada, görsel film materyalinin çözümlenişinde göstergebilim ve sosyolojik film analiz yöntemlerinden yararlanılmıştır. IIlkine filmdeki görsel materyalin yan anlamlarının içerdiği ideolojik koşullamaları açığa vurmak; ikincisine ise, toplumsal ve kültürel değerlerin filme nasıl yansıdığını ve film retoriğinin şekillendirdiği toplumsal sistemin genel özelliklerini ortaya koyymak için başvurulmuştur. Çalışmada The Platform filminin yorumlama çerçevesi, neoliberal toplumsal dizge ve panoptik gözetim ilişkisi temelinde sınırlandırımıştır. Bilindiği üzere, görüntüsel göstergeye dayalı içeriğin anlatıda düşünce ve anlam yaratma, ima etme veya var olan anlamı gizleme işlevi filmin metaforik ve sembolik dilinin açımlanışında hayati bir öneme sahiptir. Ünlü ABD'li göstergebilimci Charles Sanders Peirce'e göre gösterge, "nesnesine herhangi bir gerçek ya da temel karşılık gelme olmaksızın uyum sağlayan bir temsildir" (1982, s.323). Nesne ile göstergesi arasında herhangi bir nedensel ilişki olmadığı zamanlarda bile gösterge bir anlam veya düşünce yükü taşır. Yani gösterge her koşulda mevcuttur. Yine Peirce'e göre, nesne ile göstergesi arasındaki temsil belirtisel, görüntüsel veya sembolik (uzlaşımsal) nitelikte olabilir. Her üç gösterge türü de, anlamsal bir göndergeye sahip olduğu içindir ki, gerçekliğin ve düşüncenin inşasında büyük rol oynar. Göstergebilimsel yöntemin diğer önemli sözcüsü Roland Barthes ise, zihinsel algılamanın ilk akla gelen anlamı, yani göstergenin sözlükteki anlamı ile, dolaylı anlamı arasında bir ayrıma gider. Asıl ideolojik etkinin de göstergenin bu ikinci ve görünmeyen anlamı içinde gömülü olduğunu söyler Barthes. Göstergenin bu ikinci ve dolaylı anlamına "yan anlam" adını veren düşünür, ilkinin göstergenin anlatım, ikincisinin içerik düzlemini oluşturduğunu vurgular. Dilsel veya görüntüsel olsun, her koşulda gösterge bir anlamlar ve adlandırmalar dizgesidir. Gerek görüntüsel gösterge türünün filmin metaforik evreni içinde tuttuğu imtiyazlı yer, gerekse kimi metin ve sembollerin içerdiği olası anlam katmanlarının yoğunluğu nedeniyle, çalışmada her iki düşünürün kavramsal terminolojisinden de yararlanılmaya çalışılmıştır. Filmin sosyolojik boyutta sunduğu mesajlarsa sosyolojik film çözümleme yöntemiyle analiz edilmiştir. Bu yöntemde filmlerin sosyal bilimlere dayalı kavramsal çerçeveler eşliğinde sosyolojik ölçütlere göre değerlendirilmesi esastır. Söz konusu yöntemde filmler, Hasan Akbulut'un deyimiyle, "sosyal bir sanat ve kültür ürünü olarak eleştirilmektedirler" (2010, s. 258). Aynı şekilde, bu yöntemde film yaratıcının öznel bakış açılarını merkeze alarak değil, daha ziyade üretildiği dönemin toplumsal ve kültürel özellikleri bağlamında dikkate alınmakta olup, toplumsal, siyasal ve kültürel değerlerin filmlere ne şekilde yansıdığı ve toplumsal gerçekliği nasıl yansıttığı üzerinde durulmaktadır. 


\section{Gözetim, İktidar Mikrofiziği ve “Nekro-politika”}

David Lyon'a göre gözetleme, "hakkında veri toplananları etkileme veya idare etme amacıyla tanımlanmış ya da tanımlanmamış herhangi bir kişisel veri toplanması ve işlenmesi" olayıdır (2006, s.13). Bu tanımdan da hareketle denebilir ki, gözetleme etkinliğinin alanı oldukça geniştir. Özellikle veri gözetimiyle birlikte, internet ve ona bağlı olarak gelişen bilgi işlem teknolojileri, pastoral, teknik, vb. klasik gözetim biçimlerinin çok ötesinde, gözetimi bireyin fiziksel ve görünür mevcudiyetinden genetiğine yaymışlardır. Elektronik ve dijital olarak verilerin işlenmesi yoluyla, yeni teknolojiler bireyin bedeni üzerinde bir tür iktidar mikrofiziği oluşturmuş, sözgelimi havaalanlarındaki x-ray cihazları, mevcut kural ve yetki sınırları içinde, koordinasyon veya güvenlik gibi gerekçelerle fiziksel hareketliliğin aşamalarını gözetleme işine tahsis edilmiştir. Dahası, incelmiş kimi klinik gözetim aygıtlarıyla ayrı ayrı beden parçaları dahi gözetlenir hale gelmiştir. Kuşkusuz tüm bu gelişmelerin öncesinde, Michel Foucault'nun "disipliner" şeklinde adlandırdığı bedenlerin itaat etmenlerinde yarar payı dayatan yöntemler bütünü vardır. Buna göre beden üzerindeki zorlayıcı ve baskıcı kuşatmaların tarihi çok eskilere dek götürülebilir; beden aşağı yukarı her toplumda, hukuki veya tıbbi, birtakım zorlamalar, yasaklamalar veya zorunluklar dayatan disiplinci iktidarların nezareti altında tutulmuştur. Sözgelimi savaşma becerisinin ön plana çıkartıldığı ordudaki askerler, kilise gibi kurumlarda dini eğitime tabi tutulan ve büyük ölçüde dünyevi arzu ve ihtiraslardan soyutlanan bireyler, toplumsal düzeni bozma potansiyeli olduğu düşünülen "sapkın" ve suçluların tutulduğu hapishanelerdeki tutuklular, vb. tarih boyunca türlü gerekçelerle iktidar tarafından zapturap altına alınmıştır. Tüm bu bireylerin bedenlerinin denetimi çoğu noktada iktidardadır. Ancak iktidar bu işlevini birtakım beşeri ve pozitif bilimsel disiplinler aracılığıyla icra etmektedir. Hatta bazen kriminal vakalar düzleminde... Nitekim Dany Lacombe, "Tehlikeli illişkiler: Foucault ve Kriminoloji" başlıklı çalışmasında (1993), Foucault'nun gözetim, disiplin ve özellikle suçbilimiyle ilgili kavramlarının 1960'lı yıllardan itibaren refah devleti uygulamalarının etki alanının genişlemesiyle birlikte tüm toplumsal kurumlara yayılarak bilimsel bir görünüm kazandığını belirtir. Lacombe'un sözünü ettiği şey, Foucault sayesinde suçbilimle ilgili tasavvurun bedensel ceza ve gözetime gitgide daha yasal bir çerçeve kazandırarak set çektiğidir (1993, s.52). Bu anlamda düşünürün 1975 tarihli klasikleşmiş yapıtı Gözetleme ve Cezalandırma da, temelde bir polis devletini tanımlar. Bu polis devletinde her ne kadar var olan disiplinler normatif uygulamaları güvence altına alan araçları sunsa da, açıkça ne polis ne de katı disiplinci yönetmelikler öncelikli normatif gözetim uygulamaları değildir. Foucault'ya göre, bedene sızan ve orada çok büyük mesafe kat eden iktidar -bu noktadan sonra artık "biyoiktidar"-, ceza uygulamaları incelikli tekniklerle (klinik psikoloji, hukuk, vb.) reforme edildikçe peyderpey bedenlerden ruha yönelecektir. Foucault'nun da isabetli biçimde öngördüğü gibi, 18. yüzyılla birlikte etkileri hissedilmeye başlanan ceza ve infaz reformları bir tür yeni "iktidar teknolojisi", ruhlar üzerinde farklı kontrol biçimleri üreten bir mekanizma gibi görünmeye başlar. Artık bu sonuncu noktada, iktidarın cismani varlığını, bedende bıraktığı izlerden hareketle tespit etmek gittikçe zorlaşmaktadır (Lecombe, 1993, s.55). 
Matthieu Merlin ise, Foucault'nun toplumsal bünyenin iktidar tarafından kuşatılmasına yönelik düşüncelerini bilginin çeşitli kurumlar ve toplumsal ilişkiler arasında yaratıı̆ı "düzenleyici" işlevler açısından okur. Merlin, daha da ileri giderek Gözetleme ve Cezalandırma'nın merkezinde, toplumsal bedenin oluşması problemi olduğunu söyler. Merlin'e göre, "toplumsal beden"in somut olarak nasıl kurulduğunu anlamak için, Foucault'nun işaret ettiği biçimiyle, iktidarın sadece soyut ve muhayyel bir şey olmayıp, her şeyden önce bir ilişki, "eylemler üzerine bir eylem", aynı zamanda bir tür "davranış yönetimi" olduğunun da bilinmesi gerekir (2009, s.52). Gerçekten de Foucault'yla birlikte bazı mitlerin yıkılması söz konusudur; özellikle de her şeye kadir devlet veya sermaye veya her ikisinin müttefikliğiyle ortaya çıkan alimi mutlak iktidar gibi tanımlamalar ve terkipler yeni baştan değerlendirilmeyi gerektirir. Foucault, bu anlamda toplumsal yapının oluşumunu ve bütünlüğünü sağlamaya yönelik değerlerin kapasitesine inanmaz. O da, diğer pek çok sosyolog ve düşünür gibi, bazı gelişmelerden bahseder, ancak ona göre bireyselleştirme asla yasal dönüşümün motoru değildir; aksine, bireye asıl farklıı̆ıın veren, diğer bireysel bedenler üzerinde eylemde bulunmasını sağlayan şey, iktidar ekonomisini etkileyen değişkenlerdir (Merlin, 2009, s.53). Foucault'ya göre, iktidar konusunda oldukça karmaşık mekanizmaları hesaba katmak gerekir; "bedenlerin bu yeni ekonomi politiği, bağrında bir güçler kompozisyonunu büyüten klasik çağın sonlarına tarihlenir" (Merlin, 2009, s.53). Dolayısıyla, bedensel denetimin çehresinin değişmesiyle birlikte, iktidarın etkisi de değişir; artık çok daha fazla etkileme alanına sahiptir. Daha da önemlisi, iktidar, baskı araçlarından önce gerçekliği üretmeye koyulur. Bu noktada beden de iktidarın yüzeyine temas etmeden hırpaladığı bir kütle olmaktan çıkar artık; Merlin'in deyişiyle, "iktidar salt şiddete indirgenemez, o bizatihi yaratıcı gücün ta kendisidir" (2009, s.54).

İktidar mekaniğinin hukukun ve klinik psikolojinin de yardımıyla kat ettiği bu görkemli mesafe ile 19. yüzyılın ilk yarısından itibaren kurumsal yapılar içinde kök salmaya başlayan disiplinci pratikler birbiriyle akrabadır. Foucault'nun deyimiyle, gitgide bir fabrika düzenini andırmaya başlayan total kurumların (akıl hastaneleri, işlikler, kışlalar, hapishaneler, vb.) icadı modern disiplin toplumlarının ete kemiğe bürünmesini sağlar. Söz konusu kurumların yegane varlık nedeni ise, toplumun güvenliklileştirilmesi ve ekonomik verimliliği artırmak amacıyla bireylerin zihinsel ve bedensel varlıklarına türlü yollarla el koymaktır (Foucault, 2006, s.211). Foucault, aynı zamanda bu kurumların disiplinci fonksiyonlarının izini sürerken, bir tür "siyasal anatomi"nin de keşfini yapar. Bu kurumların her biri içinde küçük, ancak oldukça özenli disiplin ve denetim pratiklerinin (yönetmelikler, teftişler, çizelgeler, vb.) iktidar mikrofiziğinin şekillenmesinde büyük etkisi vardır. Özellikle de disiplinin, eylemlerin belli bir mekan içine dağıtımasıyla ilişkili yapısı, gözetimin bir mekanın örgütlenişine tekabül eden boyutunu öne çıkarır (Foucault, 2006, s.217). Bir sonraki adımda ise, bu gelişmeyi faaliyetlerin denetimi izler: Eylemler, en ince ayrıntısına kadar unsurlarına bölünerek, yönleri, genişlikleri, hareket süreleri kılı kırk yararcasına tayin edilir ve nihayetinde bu hummalı muhasebe, sonradan ödül veya cezaya esas oluşturur. The Platform filmi bu açıdan dikkate alındığında, söz konusu ödül ve cezalandırma sisteminin mahkûmların eylemleriyle yiyecekler arasındaki ilişkiye sızan gözetimci 
bakışla sağladığı söylenebilir. Yine bu bakımdan, deyim yerindeyse, filmde "iktidarın görünür varlığının kanıtlanamaz olması ilkesi"ne (Foucault, 2006, s. 297) göre işleyen ve "görülmeden gözetim altında tutan hapishane düzeni" (Foucault, 2006, s.289), koşullarını-hiç kuşkusuz tuzaklarını da- kendi elleriyle hazırladığı ödül ve cezalandırma sisteminin tribünlerdeki tek seyircisidir. Yemekler bariz bir hijyen ve yüce bir görev duygusunun timsali, işin erbabı kişilerce büyük bir dikkat ve özenle hazırlanır, mizansene eklenen yiyecek bolluğu görüntüsü, az sonra açgözlü insan doğasının pençesinde can vermek üzere yola çıkar; ancak nezaket ve düzen sadece görünüştedir; zira mutat gösteri çok geçmeden umulan sonucu verecek, hüküm gerçekleşecektir. Gözetlenmeden gözetleyen hapishane sistemi, gözetimin sıfır maliyetli muhasebesi içinde, adeta ödünsüz ve kusursuz bir işkence düzeneği gibi işlemektedir; vahşi kapitalist doğaya sunulan, deyim yerindeyse ıslah edici bu haz ve ego tuzağından hiçbir mahkûmun dürtülerine hükmederek sağ çıkabilmesi mümkün değildir. Dahası, söz konusu hapishane düzeni içinde cereyan eden olaylar, adeta neoliberal kapitalist düzenin baş tacı ettiği değerlerin ve bu değerler tarafından biçimlendirilmiş yaşam tarzlarının sınandığı bir deneyi andırmaktadır. Bu durum, klasik panoptik denetimin genel mahiyetiyle de örtüşmektedir büyük ölçüde. Zira panoptikon, Foucault'nun da belirttiği gibi, "insanlar üzerinde deney yapabilmek ve onlarda sağlanabilecek dönüşümleri çok güvenilir biçimde çözümlemek konusunda ayrıcalıklı bir yerdir" (2006, s.301).

\section{Neoliberal Yaşama Teknikleri ya da Yeni “Doğa Düzeni”}

Gözetimci pratiklerin neoliberal düzenle kesiştiği noktada beliren manzaraya gelince; öncelikle neoliberalizmin meşru birey tanımı, kendi yalnızlığını özgürlüğünün sabit koşulu sayan bir varlık fikrine dayanır. Bu saptama başlangıçta kulağa katı ve mutlak bir hükümmüş gibi gelebilir. Ancak siyasal ve toplumsal bir program olarak yaklaşık elli yıllık bir maziye ve inşa sürecine sahip bir dizgenin tüm dünyada özgürlük diye kafalara kazımaya çalıştığı şeyin -şimdiye dek küresel ölçekte deneyimlendiği biçimiyle- gerçekte bir girişimcilik ve satın alma özgürlügünden öteye gidememiş olması bile böyle bir yargıya varmak açısından yeterlidir. Şu bir gerçekliktir ki, neoliberal çağın değer ve düşüncesiyle biçimlenmiş bireyi, yetinmeyi ve kendine yetmeyi bilmeyen iştahıyla kışkırtımış arzuların hedefinde yer alır; dahası, sonu gelmez bir arzular söylencesi içinde yaşar. Söz konusu söylencenin nihai varış noktasında ise, açgözlülük, bencillik ve sorumsuz fırsatçılık olmadan başarılamayacak olan karanlık bir ütopya vardır. Bourdieu'nün veciz biçimde betimlediği gibi, yaratılmaya çalışılan bu kara ütopya "dünyayı dolaşan, bir uçaktan ötekine atlayan, dört yaşam yaşasalar da düşlerinde bile harcayamayacakları düşsel gelirleri olan" (2006, s.35) az sayıda insandan oluşur. Geriye kalanlarsa zaten sistemin öz-sömürü programları ve öz-sorumluluk telkinleriyle en dipte tuttuğu artıkları, plebleridir. Dahası, çalışanlara "öz sorumluluk verme stratejileri" bizzat öz-sömürüyü onların ruhlarında ve bedenlerinde cisimleştirmeye yarayan araçlardır (Bourdieu, 2006, s.84). Kendini sömürgeleştirmeyi üretkenlik, verimlilik, sorumluluk, vb. kavramlarla bir tutan düzenin insanları için ayrıca dışarıdan bir gözetmene intiyaç yoktur. $\mathrm{O}$, tüm benliğiyle, içinde yaşadığı sosyo-ekonomik ve kültürel sistemin yarattığı uyum baskısının bir ürünüdür. En vahim olanı da, 
bu baskının etkisiyle, adeta "güven duygusu ile önem duygusunun çarmıhında bir kötülük imgesine dönüşmüştür" (Erbaş, 2015, s.227).

Insandaki kökensel güvenlik arayışını doğal bir dürtüyle açıklayan düşünürler de vardır hiç kuşkusuz ve güvenlik arayışı burada önemliliğe değil, daha ziyade hayatta kalma güdüsüne eşlik eder. Aynı nedenle; "[insan] silah kuşanıp yolculuk ederken vatandaşları hakkında, kapılarını kilitlerken hemşireleri hakkında, çekmecelerini kilitlerken çocukları ve hizmetçileri hakkında ne düşünmektedir?" (2014, s.102) diye sorar Hobbes. Umduğu yanıtsa, güvensizlik hissinin her şeyden önce doğal düzenin zorlamalarıyla ilgili olduğudur. Nitekim başyapıtı Leviathan'ın izleyen sayfalarında aynı doğrultuda şunları ekler Hobbes: "Hem özgürlüğü hem de diğerleri üzerinde hâkimiyet sahibi olmayı seven insanoğlunun, [ortada] onları cezalandırma korkusuyla birbirlerine bağlayacak görünür bir güç yokken doğal tutkularının sonucu olan (...) sefil savaş şartlarından kendilerini kurtarmaları" olanaksızdır (2014, 133-134).

Deyim yerindeyse, tüm önermeleri ve dijital medyanın virütik PR teknikleriyle güçlendirilmiş retoriğiyle, hayatın her alanında yeni bir doğa düzeninin kurgusunu yapan günümüz neoliberal düzeninde ise, her iki duygu biçimi de sadece hayatta kalmaya değil; yoğun biçimde bir tek şeye, saygın bir hayatın yegâne nişanesi olan tüketici olmasına bağlıdır.

Neoliberal ekonomik düzenin "çok tüketen, az tasarruf eden, geliri yetmediği zamanlarda dahi talebini canlı tutan insan modeli" kurgusuna (Kozanoğlu, vd., 2008, s.100) uymayan yoksullar, aylaklar, evsiz-barksızlar, tüketim karşıtları ve loser $^{1}$ kategorisine giren daha başkaları sistemin çarklarını yeterince yağlayamadıklarından "çölvari bir dünya" nın insanlarıdır (Bauman, 2001, s.118). Bu insanlar zorunlu olarak müsrif değildirler; yetinmeyi, arzularını dizginlemeyi kâmilen bilirler; ve adeta İbni Haldun'dan aşina olduğumuz bedevi bir ümranın ahlakı ve görünüşü bakımından birer nefaset ehlidirler. Ne ki, tüketmeye yönelik bu iştahsızca yönelim, bu sistem tarafından asla "fiyatlanamayan" eğri, sistem açısından bir değer oluşturmadığından kesinlikle tanımlanamaz bir eylemdir. Bu gibi kimseler, sadelikleri ve arzularına gem vuruşları bakımından asla idealize edilemezler. $\mathrm{Ne}$ de, "Tanrı birine fazla meyve vermişse, o kişi, meyveler elinde çürümemesi için ondan kardeşlerine vermelidir" (Scheurmann, 2016, s.63) diyen şu erdem timsali Samoa yerlisinin ögüdüne tabidirler; tüketime karşı direnci belli bir siyasal ve etik programın gereği olarak kurgulayanlar hariç, çoğu yalnızca zorunluluktan öyledirler. Salt tüketimle etrafında bir güvence ve saygınlık arayan kişiyse, hayatında

1 John Berger, sistemin 'loser' diye damgalayarak hayatın çeperlerine fırlattığı düşük sosyo-ekonomik statü katmanına dâhil bireylerin ekonomik bir ayrımcılığın kurbanları olduğunu belirtir. Mükemmel bir "kaybeden" olarak loser, bu yönüyle sistem kaçağı bir uyumsuz, egemen değerlerle biçimlenmemiş ya da sistemin ekonomik nedenlerle biçimlendirmeye gerek duymadığı biri, flâneur'ün gözden düşmüş bir versiyonudur. "Neoliberalizm" diye yazar Berger, "ekonomik faşizmdir, çünkü dışlanan ve yoksulluğa mahkûm edilen insanlar piyasacıların zihniyetinde 'loser'dır, kaybetmeye, başarısızlığa yazgılıdırlar" (2016, s.37). Bu konudaki daha ayrıntılı çözümlemeler için bkz: John Berger, İstanbul'dan Gelen Telefon. Müzik Eşliğinde Bir Söyleşi, çev. Yücel Göktürk, Metis Yayınları, 2016. 
iyelik eklerini çoğaltmak dışında bir özgürlük ve refah biçimi tasavvur edemez. İlksel yerlinin "papalagi" adını verdiği bu sonuncusu, -kendi türüne ve doğaya hükmetmekten başka bir ilişki biçimi tahayyül edemediği için- yeryüzünün her milimetrekaresine karşı yabancılaşmış biridir. Dahası, dillere destan bencilliği ve zorbalıkta sınır tanımayışıyla, papalagi öyle birisidir ki, "sadece kendi kulübesinin önünde yetişti diye 'Bu palmiye benimdir!' diyebilir. Sanki onu yetiştiren kişi kendisiymiş gibi..." (Scheurmann, 2016, s. 58).

The Platform filminde de neredeyse bencilliğin kötücül imgelerinin tüm boyutları mevcuttur. Mahkûmlar yemek sofrasına sadece iki dakikalığına buyur edilirler; elini çabuk tutan, hızın içinde gereğince yol alabilen karnını doyurabilir. Bu bile, kapitalist ahlakın sistemleşmesinde önemli katkısı olan ünlü "vakit nakittir" düsturunun vaaz ettiği gerçekliği doğrulayan altın değerinde bir sahnedir. Gelgelelim bu kısacık süre bile mahkûmların sofranın üzerinde tepinmeleri için yeterlidir. Bu gözü dönmüşçesine açığa vurulan açgözlülük histerisinde diğerlerinin açlığı akla bile gelmez. Sistem adeta mahkûmları dürtülerine hükmederek denetler. Bu nedenle, filmde işleyen gözetim düzeneği dürtüsel benliğin kışkırtıması ilkesine dayanır. Söz konusu kışkırtma, mahkûmlar arasında bir tür kusursuz uyumluluk ilişkisi yaratır. Öylesine duyusal uyarılmaya öncelik veren bir düzen kurulmuştur ki, durum Hobbes'un güçlü olanın hayatta kaldığı doğa düzenini akla getirir. Bu düzende herkes herkesin kurdudur adeta ve herkes birbirinin zayıflığından güç devşirir. İktidar herkesin, herkes de birbirinin arzusunun denetleyenine dönüşür. Filmde yeme hiyerarşisinin yönetimi ve açgözlülüğün kontrolü tabakalı toplum modeline göre yapılanmıştır. Üst kattakiler, deyim yerindeyse, gökyüzü manzarasını gönüllerince satın alabilirken, alttakiler zemin kat ekonomisinin kasvetli havasını solumaya mahkûm edilmişlerdir. Böylesi eşitsizlikçi bir düzende, doğal olarak otokontrolün sağlanabilmesi için bencillik dışında bir paylaşım düzeninin ve onun değerlerinin tesis edilmesi gerekir. Gerçekten de mahkûmlar filmde olası kolektif imkânları daha da körelten bir güdünün, bencilliğin denetimindedirler. Bencillik vurgusu bizzat filmin yönetmeni Galder Gaztelu-Urrutia'nın BBC'nin İspanyolca servisi BBC Mundo'ya verdiği röportajda da oldukça belirgindir: "Eğer platforma yemek yerine tuvalet kâğıdı veya yüz maskesi koymuş olsaydık" demektedir Gaztelu-Urrutia, "insanlar yine aynı şeyden bahsediyor olacaktı: Yüreklerimizin derinliklerine dek işleyen bencillik" (www. cumhurriyet.com.tr, 12.04.2021). Filmde biri medeni (Goreng), diğeri açgözlü (Trimagasi) iki zıt karakter vardır. Yönetmene göre aslında aynı kişiliğin iki farklı yüzüdür her ikisi de. Illki olmak istediğimiz, diğeriyse gerçekten olduğumuz kişiye karşılık gelir. Ne var ki, sonunda savaşı ikincisi kazanır. Dolayısıyla filmde gıdayı, barış̧̧ı bir yöntemle her kattaki mahkûmlar arasında eşit dağıtmak isteyen Goreng'in amacı gerçekleşemeden kalır (yanına aldığı Don Kişot romanının çağrıştırdığı bahtsız mecazdan da bellidir aslında makûs son), çünkü mahkûmlar arasında umulan dayanışma bir türlü gerçekleşememektedir. Bu başarısızlığın bir nedeni, filmde mahkûmların tutuldukları katın ayda bir rasgele değişmesi ve birbirlerine güvenip birbirleriyle güç/iş-birliği yapacak kadar birbirlerini tanıyamamalarıdır kuşkusuz. Deyim yerindeyse, "katlar değiştikçe mahkumların kendi vicdan ve ahlak stratejilerinin de büyük ölçüde erozyona uğraması", (https://seyler.eksisozluk. com, 23.03.2021) böylesi bir dayanışmaya engeldir. 
Özellikle de farklı toplumsal tabakalar arasındaki farklar belirginleştikçe, söz konusu uçurum daha da artmaktadır. Sakine Esra Yalçınkaya da, "The Platform -El Hoyo-Delik-Filmi Üzerine" başlıklı yazısında, filmin kahramanı Goreng'in ilk sahnede mırıldandığı "Üç tür insan vardır: Yukarıdakiler, aşağıdakiler ve düşenler" sözünü temel alarak, filmin dikey biçimde örgütlenmiş toplumsal manzarasının ardında sınıflı bir toplum yapısını görür (https://sendika.org, 26.04.2021). Filmin özünde bir sistem eleştirisi yaptığını vurgulayan yazar, özellikle sol tandanslı politik eleştirinin doğrudan kapitalist sistemin ideoloji ve değerlerini hedef aldığını belirtir. Buna göre, mahkûmların "içinde bulundukları delik dünyayı, yönetim devleti/erki/iktidarı, katlar da sınıfsal farklıı̆̆ temsil etmektedir" (Yalçınkaya, https://sendika.org, 26.04.2021). Bu konuya filmin analiz kısmında ayrıntıı biçimde değineceğimizden burada noktalıyoruz. Sonuçta filmin önerdiği çözüm rejim değişikliğinde noktalanır. Ancak barışçı bir çözüm değildir bu; aksine, ancak şiddetle başarılabilecek bir devrimdir... ${ }^{2}$

Filmdeki temel sorun özgürlük arayışı değildir, sistemin yüklenilmiş hormonlarından -gerek mistik gerekse politik açıdan- özgürleşme cihetidir daha ziyade. Nitekim Han'ın da belirttiği gibi, "Neoliberal rejimin iktidar tekniği yasakçı, korumacı ya da baskıcı değil, ileriye dönük, müsamahakâr ve destekleyici" (2019, s.46) olduğu içindir ki, baskının görünmezliği ve bu durumun sıradanlığı, özgürlükmüş gibi deneyimlenir. Böylelikle, açlık korkusuyla tüketmenin verdiği vahşi hazla, ahlaki sorumluluk duygusu da askıya alınmış olur. Benlik, ideoloji ve düşünceden tümüyle arınır. Artık bir kontrol ve karar merkezi olarak beyin değil, güdülerdir devrede olan. Özetle, The Platform'un vahşi doğal düzeni andıran gözetim düzeneği, bu yönüyle psikolojiden/ vicdan yükünden arınmış paranoyak özneler imal etmeye dönüktür. Bu, gerçekten de yeni bir hayat tasarımı veya yaklaşmakta olana alıştırmak açısından oldukça manidar bir durumdur.

Son olarak, The Platform'da beden denetimine koşut olarak bir tür nekro-politika biçimi de yürürlükte gibidir ve bu kavram da doğrudan neoliberal reflekslerin bir ürünüdür. Bilindiği üzere, Mbembe, "Necropolitics" başlıklı makalesinde, politika okumasını geniş bir tarihsel sürece yayarak ve kuşatıcı bir perspektif içinde ölüm kavramıyla ilişkisi bağlamında değerlendirmeye çalışır. Yazar, ağırlıklı olarak "öldürme hakkı" olarak ifade edilen bir tahakküm biçimine odaklanarak; "Öldürme hakkı" diye yazar, "istisnanın ve düşmanlık ilişkisinin normatif temeli haline gelmiştir" (Mbembe, 2003, s.16). Başka bir deyişle, Mbembe'ye göre öldürme hakkı tartışmalı bazı hukuki gerekçelerle bizatihi toplumsal bir meşruiyet arayışının politik zemini yapılmıştır. Tarihsel perspektiften bakıldığında, bir dizi analist gibi, Mbembe de Nazi imhasının maddi öncüllerini sömürge emperyalizminde bulur ve ilaveten, teknik mekanizmaların serileştirilmesinde insanları ölüme mahkûm

2 Ancak bu tespiti paylaşmayan, filmin mücadele anlayışının devrimden ziyade "adil bölüşüm"e evrildiğini iddia eden kimi görüşler de vardır. Bu anlamda, filmin asıl hedefini yalnızca "yemeğin dağıtımını organize etmek"le, dolayısıyla bir tür reformla sınırlayan ve filmin önermelerini benzer hedefleri paylaşan daha başka edebi distopya örnekleriyle birlikte okuyan bir değerlendirme için bkz: Veysi Çetin, "Bong'un Treninden Vincenzo'nun Küp'üne The Platform'a Bir Bakış", https:// www.gazeteduvar.com.tr/sinema/2020/04/20/bongun-treninden-vincenzonun-kupune-the-platforma-bir-bakis, Erişim 12.05.2021. 
etmenin büyük ölçüde Sanayi Devrimi ile Birinci Dünya Savaşı arasında geliştirilen mekanizmalarla ilgili olduğunu vurgular (2003, s.18). Mbembe, aynı yerde, Marx, Foucault, Carl Schmitt, vb. düşünürlere referans vermek suretiyle, biyoiktidar ve düşmanlık ilişkisini kimi somut tarihsel olaylarla bir arada düşünür. Biyoiktidar kavramını özellikle geçmişteki emperyal savaşların yerel güçleri yok etmek ve sivil nüfus üzerinde yeni askeri kontrol modelleri oluşturmak gibi amaçlarla birlikte tasavvur eden Mbembe (2003, s.25), ardından geç-modern kolonyal işgal koşullarında nekro-iktidarın işleyişini çağdaş savaşlarla (Bosna Savaşı, Filistin direnişi, vb.) ilişkisi bağlamında tartışmaya açar (2003, s.30). Mbembe'ye göre, ebediyet arzusuyla kuşatılmış beden iki aşamadan geçer. Birincisinde beden basit bir şeye, şekillendirilmeye müsait bir maddeye dönüşür. İkincisinde ise, hangi şekilde (idam, infaz, intihar, vs.) sonlandırımışsa, ona nihai anlamını veren şey de odur (2003, s.37). Olağan döneminde genellikle ilki, savaş ve çatışma dönemlerinde ise ikinci boyutuyla gündeme gelir. Ancak ırksal nefret, terörizm, salgın hastalıklar, vb. durumlarda da nekro-iktidarın yürürlükte olduğu incelikli kimi uygulamalar görülebilir. Mbembe'nin kullandığı biçimiyle, "yaşamın, ölümün iktidarına tabi olması" yahut "kimin yaşayıp kimin öleceğine karar verme egemenliği" (2003, s.18, 22) şeklinde tanımlanabilecek olan nekro-politik tutum, The Platform filminin hemen her karesine sinmiş gibidir. Filmde, hayat her an gerçekten de açlığın sürekliliği veya karnını doyurabilme güvencesinin yokluğu biçiminde ölümle iç içedir. Bu anlamda nekro-politika, neoliberalizmin değerleriyle doğal seleksiyonun kesiştiği noktada doruğa çıkar. Güçlüler ve içinde bulunduğu koşullara direnç gösterebilenler hayatta kalır; bunu başaramayanlarsa elenirler. Tıpkı doğa düzeninde olduğu gibi...

\section{The Platform Filmi ve Muadillerinden Farkı}

The Platform filminin distopik evreninde bireyin temel fizyolojik ihtiyaçları dolayısıyla bedeni muhtelif yaptıımlarla (açlıkla cezalandırma veya ödüllendirme) uzaktan gözetime tabi kılınmaktadır. The Platform muadili filmlerde de gözetim farklı tezahürlerde görünür kılınmıştır. Sözgelimi, Florian Henckel von Donnersmarck'in yönettiği, 2006 yılı yapımı Başkalarının Hayatı isimli filmde, kamu güvenlik biriminde görevli çalışanın başlıca görevi muhalif öğeleri belirleyip raporlamaktır. Kendisine bir tiyatro yazarını takip etme görevi verilen istihbarat çalışanı, yazarın evine dinleme cihazı yerleştirir ve fütursuzca başkalarının hayatına dâhil olur (Medin, 2019, s.159). Bu filmde gözetim, bireyin mahremiyetinin güvenlik gerekçesiyle ihlal edilmesine dayanır. Yine söz konusu filmdeki gözetim stratejisi dinleme cihazı aracılığıyla gerçekleştiirlen geleneksel bir yönteme karşılık gelirken; The Platform'da dijital nitelikli ve katı bir yaptırıma dayalıdır. Diğer bir deyişle, The Platform filmindeki gözetim daha gizemli teknolojik araçları/kanalları kullanmakta ve bu yönüyle Başkalarının Hayatı filminden ayrılmaktadır. Aynı şekilde, gözetim konusunu işleyen bir diğer güncel örnek de Açlık Oyunları film serisidir. Bir roman uyarlaması olan Açlık Oyunları serisinin ilk filmi 2012'de gösterime girmiştir. Panem adlı distopik bir ülkede geçen filmde "Capitol" adıyla bir başkent ve Capitol'e bağlı mıntıkalar bulunmaktadır. Capitol'ün gösterişli yaşamına karşın; mıntıkada yaşayanlar açlık ve sefaletle yüz yüzedirler. Filmde mıntıklardaki gelişmeleri Capi- 
tol'e bildirmekle yükümlü muhafızlar bulunmakta ve böylece mıntıka halkı sürekli gözetim altında tutulmaktadır (Diken Yücel, 2015, s.393). Açlık Oyunları filmi de tıpkı The Platform gibi gözetim meselesini distopik bir evrene taşımaktadır. Görece daha eski bir yapım olarak, The Truman Show (Peter Weir, 1998) filminde ise "artık gözetleme tek bir merkezi güç tarafından yapılmamakta, gözetlenenler aynı zamanda gözetmektedirler. Toplum tek taraflı gözetimin yapıldığı gözetim toplumundan çift taraflı gözetleyen ve gözetlenen durumuna geçmiştir" (Sucu, 2020, s.11). Süperpanoptik bir niteliğe sahip olan film, bir yönüyle de televizyonun tutsak alma işlevini sorgulamaktadır. Fahreinheit 451 (François Truffaut, 1966), 1984 (Michail Radford, 1984) ve Sorun Yaratan Adam (Jens Lien, 2004), $\checkmark$ for Vandetta (James McTeigue, 2006) gibi filmlerde de genel olarak panoptik denetim biçimini otoriter bir toplumsal yapılanmayı daha da görünür kılmak için inzibati veya sıhhiye toplumu ilkeleriyle sentezleyen bir eğilim göze çarpmaktadır. The Platform filminin tüm bu film örnekleriyle güçlü ortak yanları bulunmasına karşın -muhtelif saiklerle mahremiyetin göz ardı edilmesi, bireyin bedeninin katı biçimde disipline edilmesi, vb.-, öldürme ve yamyamlığa varıncaya dek vahşet dolu görüntüler içermesi ve neoliberal yaşam düzenini kıyasıya hicvetmesiyle önemli ölçüde onlardan ayrılmaktadır. Özellikle bu sonuncu boyut, The Platform filmini ayrıcalıklı kılan özelliklerden bidiridir ve beden denetimini bir tür biyopolitik kavram düzleminde ele alarak, neoliberal dünya düzeninin bütün yapıcı seslenişine rağmen bireyin ilkel dürtülerini harekete geçiren niş noktalarını gözler önüne serecek tarzda distopik bir evrende yeniden tahayyül etmesidir.

\section{Analiz ve Bulgular}

İspanyol yönetmen Galder Gaztelu-Urrutia tarafından yönetilen 2019 yapımı The Platform filminin dağııımı dijital film platformu Netflix tarafından yapılmıştır. Filmde adına "delik" denen (filmin İspanyolca ismi "El hoyo" da tastamam delik anlamına gelir) dikey mimariye sahip bir hapishane bulunmaktadır. 333 kattan oluşan ve her katta iki mahkûmun bulunduğu bu dikey mimaride, günde bir kez üzeri tıka basa yiyecek dolu bir platform, her katta iki dakika süreyle kalacak şekilde ve h erhangi bir yiyecek takviyesi yapılmaksızın yukarıdan aşağıya doğru inmektedir. Bu durum, platformda diğerlerinden daha yukarı katlarda kalan her bir tutuklu için daha çok; daha aşağıda bulunanlar içinse daha az yiyeceğe erişim anlamına geldiğinden, adeta hiyerarşik bir yeme düzeni inşa etmektedir. Böylece filmde bireylerin beslenme düzeni tamamen kontrol altında tutulmaktadır. Alt katlara inildikçe yiyeceğe erişimi kısıtlanan ve temel intiyaçlarını karşılamakta güçlük çeken mahkûmlar, kısa bir süre sonra akli melekelerini bir yana bırakarak, tümüyle dürtüleriyle hareket etmeye başlamaktadırlar. Nitekim platformun kusursuz denilebilecek yemek sunumuna karşın, mahkûmlar hayatta kalma mücadelesiyle infiale sürüklenmektedirler. Gelinen noktada, tek gayesi karnını doyurmak olan mahkûmlar bütünüyle iaşeye odaklanmakta ve empati kurma, acıma, eyleme geçme, zihinsel muhakeme etme, sosyal normlara uyma vb. tüm yetilerini yitirmek suretiyle, adeta acımasız bir doğa düzenine doğru gerilemektedirler. Hapishanede gözetleyeni/iktidarı temsilen gardiyan ve/veya Louis Althusser'den referansla söylersek, 
"devletin baskı aygıtları" (2000, s.33) fiziken görünür değildir. Yanı sıra, söz konusu hapishane modelinde Bentham ve Foucault'cu anlamıyla gözetleme kuleleri de yoktur (Bauman ve Lyon, 2013, s.65). Ancak yine de filmdeki hapishane tahayyülü, en azından işlevi ve mahiyeti bakımından Foucault ve Bentham'ın gözetleme kuleleri ve hapishane modelinden referansla tasarlanmıştır denilebilir. Filmde gözetleme, bütünüyle uzaktan ve teknoloji dolayımıyla yapılmaktadır. Diğer bir deyişle, iktidar tamamen görünmezdir ve bireyler, daha doğrusu onların bedenleri görünmeyen bu iktidarın kontrolü altındadır. Bu noktada Foucault'nun iktidar ve beden arasında kurduğu ilişkiyi yeniden hatırlayacak olursak, ortada tahakküme bitişik bir fantazmanın, başka bir deyişle "istençlerin evrenselliğiyle oluşturulan toplumsal bir beden fikri" nin var olduğu söylenebilir (Foucault, 2019, s.43). Ancak bu beden fikri maddi bir boyuta ve biçime sahiptir, çünkü daha önce de zikrettiğimiz gibi, "toplumsal bedeni ortaya çıkaran şey konsensüs değil, bizzat bireylerin bedenleri üzerindeki iktidarın maddiliğidir" (Foucault, 2019, s.43). Buradan da anlaşılacağı üzere, toplumsal beden uzlaşı ile değil, iktidarla ve onun bedenler üzerindeki somut etkinlikleriyle zuhur eder. Dolayısıyla filmde tam da böylesi bir iktidar ve beden ilişkisine denk gelindiği söylenebilir rahatlıkla. İktidar, mahkûmların bedenleri üzerinde maddi olarak görünürdür. Zira mahkûmlar bulundukları seviyeye göre yiyeceğe erişim sağlayabilmektedirler. Sözgelimi 1. seviyede olan bir mahkûm karnını rahatça doyurabilirken, 200. seviyedeki açlıkla karşı karşıyadır. Hangi mahkûmun hangi seviyede yer alacağıyla ilgili ise, görünürde hiçbir kriter ya da kural bulunmamakta olup, bu durumda asıl belirleyici olan görünmeyen iktidarın kendisidir. İktidarın bireyler üzerindeki maddi kontrolü hapishane sisteminin işleyişini göstermektedir. Filmde iktidar düzeneğinin iki farklı uyarı düzlemini açığa vuran bir diğer ayrıntı da şudur: İki mahkûmun bir ay süreyle kalıp daha sonra aşağı ya da yukarı bir seviyeye taşındığı hapishanenin her seviyesinde biri kırmızı, diğeri yeşil olmak üzere, iki farklı şık vardır. Genelde kırmızı rengin hâkim olduğu atmosferde, ancak üstü yiyeceklerle kaplı platform aşağı doğru salınmaya başlandığında renk yeşile dönmektedir. Açıkça kırmızı rengin uyarı, yeşilin ise güvenlik anlamında kodlandığı görülmektedir.

Şimdi tüm bu bilgilerin ışığında, filmi farklı ancak birbirinden güçlü metaforik çağrışımlara sahip beş sahne ekseninde analiz etmeye çalışalım. 
Görsel 1: Üzeri türlü yiyecek ve içeceklerle dolu platform

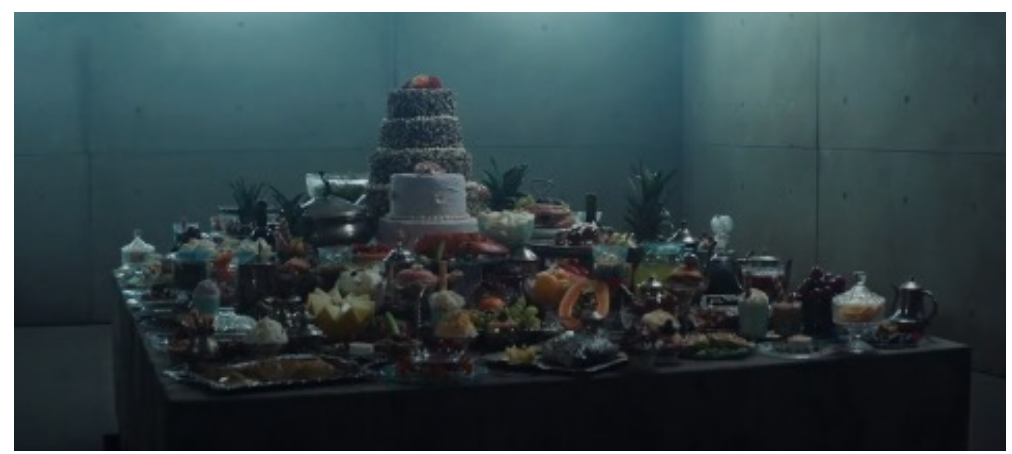

\section{Görsel 1'in Çözümlenmesi}

Gösterge: Üzeri yiyecek-içecekle dolu platform görüntüsü.

Gösteren: Kare formunda bir masa, üzerinde çeşitli yiyecekler, içecekler ve tatılır vardır.

Gösterilen:

Düz anlam: Hapishanenin en üst katından aşağı katlara doğru mahkûmların yemesi için çeşitli yiyecek ve içecekler hazırlanmıştır.

Yan Anlam: Platformadaki yiyecek içecek bolluğu ve zenginliği adeta neoliberal düzenin bolluk, çeşitlilik ve refah vaadinin somutlaşmış hali gibidir. Nitekim platformdaki tüm yiyecek ve içeceklerin görünüşte- rastgele, hiçbir yeme hiyerarşisini çağrıştırmayacak vaziyette ve dağınık biçimde yerleştirilmiş olması da bu varsayımı doğrular niteliktedir: Adeta herkesin eşit erişimine açık bir sofra düzenlemesi yapılmıştır. İkinci olarak, söz konusu düzensiz yemek yığını görüntüsü, biraz yakından bakıldığında, bir "yağma" girişimi öncesinin tekinsiz anlamına sahiptir. Bu anlamda, söz konusu yiyecek içecek bolluğu görüntüsü vahşi bir fırsatçllığa daveti çağrıştırmaktadır. Bu karenin izleyicide çağrıştırdığı üçüncü örtük anlam, insanlar için yiyeceğin en asli denetim aracı olduğu iddiasıdır. $\mathrm{Bu}$ açıdan filmde asıl vurgulanmaya çalışılan, beşeri toplumsal düzenin bariz bir eğretilemesi olarak sunulan hapishane sistemine içkin denetim, çatışma ve üretilecek rızada kilit noktalardan biri üzeri yiyecekle dolu bu platformdur.

Görsel 1'in göndergesel içeriği bolluk fikrinin düzensizliğini yansıtır. Söz konusu düzensizlik imgesi, adeta kısa bir süre sonra yaşanacak olan yağmanın da dramatik içeriğinin habercisi gibidir. Bu anlamda tanık olunan şey, ahenkli bir sofra değil, düzensiz bir kümedir. Başka bir deyişle, sofranın etrafına yatay olarak yayıımış yiye- 
ceklerin ortasında çok katlı pastanın yarattığı yükselti, mecazi bir eşitsizlik imgesi olarak, izleyen sahnelerde cereyan edecek olan olaylar arasındaki dramatik birliği sağlar. Öncelikle, Jacques Aumont'un da deyimiyle, "tıpkı tiyatroda ve resimde olduğu gibi, sinemada da sahne kavramı dramatik birlik fikrini iletir" (2005, s.176). Bu anlamda The Platform filminde neredeyse baştan sona kurgulanan sahneler, "dramatik" kavramının somut bir tezahürüdür. Dramatik boyut, sahnelerdeki patetik etkiyi yoğunlaştırmakla kalmaz, onlara hakiki kimliğini, anlamını da verir. Dramatik boyut bir bakıma sahnenin netliğini daha da yoğunlaştırmak suretiyle bozar. Filmik imge, bu açıdan Jacques Aumont'un veciz deyişiyle "toz içinde bir yürüyüşün yeridir" (2005, s.87). Kimi birbirine karşıt yoğunlukların -ışık ve gölge, siyah ve beyaz, şiddet ya da arzudeğiş tokuşunun gizemli bir şekilde granüle edilmiş alanıdır. Bunlar, ardışıklıkları durdurulamaz, öngörülemez, ölçülemez olduğu için rüyalar gibidir (Aumont, 2005, s. 87). Gaztelu-Urrutia'nın filmi, rüyadan da öte bir şey; tam anlamıyla yoğunlaştırılmış bir görsel kâbustur. Dahası, olaylar gecede ve uyurken değil, gözlerin açık olduğu bir zamanda gerçekleşir. En vahimi de, söz konusu kâbusa, gözetim, tüketim, açlık, şiddet, hayatta kalma güdüsü gibi kavramlar eşlik eder. Bu bağlamda, teknolojik değişim ve dönüşümle birlikte daha da görünür olmaya başlayan dijital mecralarda buluşan bireyler yalnızca gözetim mekanizmalarına tabi olmakla kalmazlar, aynı zamanda tüketimin de nesnesi haline gelirler. Avcı'nın da deyişiyle, dijital ortama uyum sağlamaları beklenen bireyler yönlendirilmiş bir şekilde sistemin tüketim çarkına eklemlenirler (2015, s.250-251). Tüketim döngüsünde görece elverişli konumda olanlar kendi güdülerini kontrol altında tutup, özgür tutum ve davranışlar sergileme potansiyelini haizdirler. Ancak açlıkla birlikte ve insan bedeninin fizyolojik olarak yiyeceğe güdülendiği bir zeminde sosyal normlar da zihinsel algılamanın dışında tutulur (Bkz. Görsel 2). Bu tam da vahşi kapitalist doğanın uyarıldığı andır. Böylesi bir durum, empati, sempati, acıma duygusu, paylaşım, vb. kişilerarası iletişime anlamlı boyutlar katan kimi yönelişlerle, bireyi elindekini doğal biçimde diğerleriyle paylaşmaya itecek mantıksal kararları etkisiz kılabilmektedir. Genelde tüketime sunulan kaynakların miktarından çok kullanım pratiklerinin daha önemli olduğu bilinir. Ancak ortada eğer tüketimi de aşan bir yağma hali varsa, o durumda kullanımın rasyonalitesinden nasıl bahsedilebilir? Bu nedenle teoride mümkün olan bölüşümün pratikte sorunlu olması, insanın benmerkezci doğasını da yanına alarak işlersiz bir altyapıya zemin hazırlayabilir. Filmde tüketim hiyerarşisi içindeki bireyler bir yandan panoptik mekana uyum sağlama çabası içindeyken; öte yandan ortamın gerekliliklerine itaat edip maksimum çaba ile asgari fayda sağlayıp hayatta kalma mücadelesi vermektedirler. Yani gözetim ve doğa düzeninin acımasızı̆̆ı da birbiriyle iç içedir, tıpkı yukarıda sözünü ettiğimiz gibi. Bu noktada bireyin algısı ve mantığı güdülerine yenik düşmekte ve doğal olarak bütün ilgisi, beklentisi, tutum ve davranışı da yeme-içme eyleminin tatminine yönelmektedir. Elbette böylesi bir zemin eşitsiz bir paylaşıma işaret etmektedir. Bunun için sadece filmdeki şu diyaloğu hatırlamak yeterlidir:

Goreng: "200 seviyeye kadar yiyecek inmiyor ki."

Imoguiri: "Eğer herkes kendine yetecek kadar yeseydi en alt kata kadar da yiyecek inerdi" (The Platform, 42:53-43:01). 
Görsel 2: Platformun üzerinde yiyecek arayan insanlar

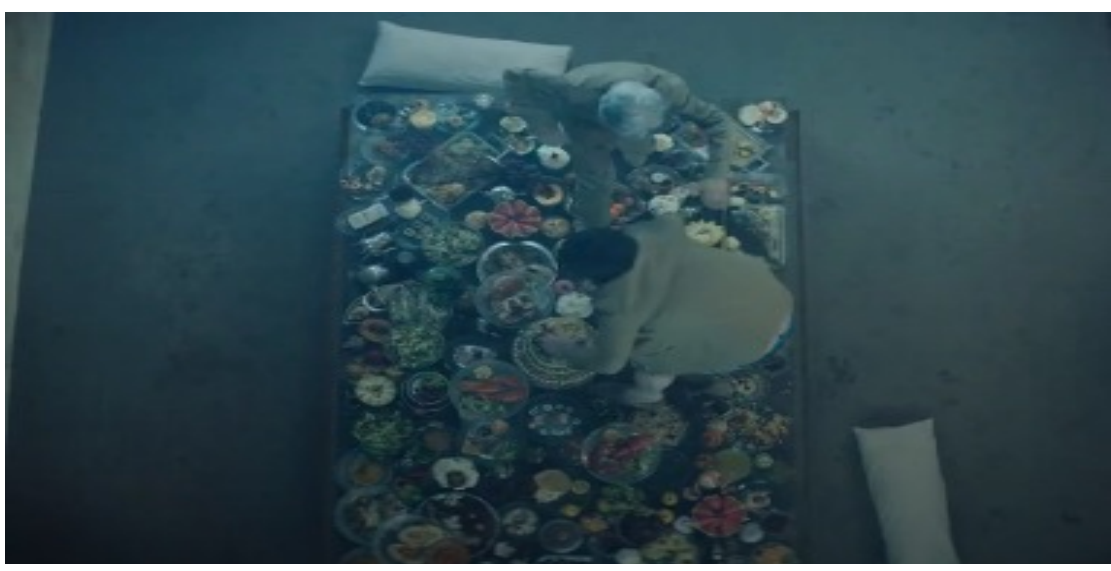

\section{Görsel 2'nin Çözümlenmesi}

Gösterge: Yiyecekle dolu platformun üzerinde yiyecek bulmaya çalışan iki mahkûm bulunmaktadır.

Gösteren: Üst açıyla çekilen görüntüde, üzerinde çeşitli yiyecekler bulunan bir platform, iki yastık ve iki insan görünmektedir.

Gösterilen

Düz anlam: Mahkûmlar platformun üzerinde yiyecek aramaktadır.

Yan Anlam: Görsel 2'de yer alan görüntü, modern insanın açlıkla sınanması halinde sosyal normlarda yaşayacağı muhtemel sapmaların ve değer aşınmalarının en somut göstergesi gibidir. Yeme eyleminin zamansal denetime tabi tutulması, bireylerin hayvani duygu ve ilkel dürtülerini harekete geçirir. Fizyolojik intiyaçlarının giderilmesi bir otorite nezaretinde belirli bir süreyle kısıtlanan bireyler toplumsal nizamın gerekliliklerinin tam karşıtı tutum ve davranışlar sergilerler. Deyim yerindeyse, içinde bulundukları bu zorlayıcı koşullarda, sofra adabı bir yana, en temel vicdani ve ahlaki stratejileri dahi çökmüş gibidir. Mahkûmların açlık dürtülerinin kontrolünde saldırgan ve telaşlı hareket etmeleri neoliberal sistemin hız ve başarı arasındaki ilişkiyi kutsayan düsturunun vücut bulmuş haline oldukça benzerdir. Ayrıca bu sahnede denetimin zamansallaştııılması (yeme eyleminin belli bir süreyle sınırlanması) açıkça bireylere ellerini çabuk tutmayı ve hızlı hareket etmeyi vaaz ederken, söz konusu durum kapitalist sistemin "doğru zamanda doğru yerde olmayı" buyuran yahut "vakit nakittir" gibi telkin ve motive edici yönünü de anımsatmaktadır. Sistemin verdiği vaaz, açlık sonucu hoyratlaşan bireyi haliyle oldukça 
mücrim kılmaktadır. Kendini kaybedercesine yemeğe saldırmak, irade gücünün zayıflamasıyla da bağlantııdır. Zira platform kendisinin bulunduğu seviyeye ulaştığında, yeme süresi başlayan mahkûmun zamanı kısıtlı olduğu için vahşiyane bir tutum ve davranış sergileme eğilimi olabildiğince yüksektir. Öte yandan, bu sahnede şayet dikkatli bakıı rsa, zımni olarak anlatılmaya çalışılan ve adeta kapitalizmin ürettiği kitlesel sefalete göndermede bulunan bir referans çerçevesi ile daha karşılaşılır: Televizyonların akşam haberlerinde sıklıkla ekranlara gelen "çöpten yiyecek arayan insanlar" görüntüsü...

Bilindiği üzere, yiyeceklerin fiziksel kimyalarının herhangi bir yolla bozulması ve herhangi bir yabancı maddenin yiyeceğe temas etmesi onun yenilebilir/tüketilebilir özelliğine zarar verir. "Yiyeceklerin kirlenmesi" motifi, bazı kasta dayalı inançlarda da önemli bir tabudur. Görsel 2'de sofrada ayaklarıyla gezinen -bazen de kusan- mahkûmlar bir yandan karınlarını doyurma çabası içindeyken, diğer yandan kendilerinden alt seviye(ler)de bulunan mahkûmların payına da zarar vermektedirler. Görsel 2'deki sahnenin üst açıyla yapılmış çekim ölçeğinin bir tür yabancılaştırma işlevi görmesi de, sofradan ve sofradakilerden uzaklaşma eğilimini çağrıştııır. Ayrıca aynı üst çekim tarzı, karede yer alan figürlerle seyircinin özdeşlik kurmasını da engeller, zira davranışlarına onay verilemeyecek bir durumda, aciz ve güçsüz bir görünümdedirler.

Öte yandan, aynı üst çekim ölçeği, üst kattakilerle alttakiler arasındaki hiyerarşik ayrıma ilaveten, panoptik gözü de özellikle gözetleyenler açısından görünür kılar. Aynı şekilde, tâbi kılınmışlar üzerinde sistemin ürettiği rızanın veya uyguladığı hegemonyanın doğrudan yüceltilmiş bir güçle de ilgisi olduğu söylenebilir. Filmde de gözetleyen iktidar yukarıdadır. Ancak iktidarın tam olarak nerede olduğu kimse tarafından bilinemez. Tam da bu noktada, filmde, Trimagasi ve Goreng arasında geçen diyalogda iktidar ve/veya yukarıda olanın ilahileştirildiği bir durum söz konusudur: "Aşağıdakilere seslenmeyin" der Trimagasi. Goreng: "Neden?" diye sorar. Trimagasi: "Çünkü onlar aşağıda" der, "yukarıda olanlar yanıt vermez." Goreng, yeniden: "Neden?" diye sorduğunda, Trimagasi ona şu yanıtı verir: "Yukarıda oldukları için tabii" (05:21-05:36).

Yukarıda olanın ilahileştirildiği böylesi bir zihinsel algıda, doğal olarak iktidarın hep "aşağı doğru karşılaştırma yapma" yı telkin edici yönüne denk gelinir. Sözgelimi herhangi bir mahkûm eğer 50. seviyede ise, 100. seviyede olmadığı için mutlu olmaııdır. (Tıpkı tabakalı toplumsal sistemlerde olduğu gibi, yükselmenin bir sınırı olmadığı gibi, düşmenin ölçüsü de yoktur; dolayısıyla hep yukarıya doğru bakmalıdır.) Yine dikey hiyerarşik örgütlenmiş toplumların geçişgen mantığına göre, herkes bulunduğu konumdan asla hoşnut olmamalıdır. Artık talep etmeyen ve yetinmeyi bilen kaybetmiştir. Bu anlamda Mill'in deyimiyle, "halinden memnun bir domuz olmaktansa (...), halinden memnun olmayan bir insan olmak daha iyidir" (2017, s.32). Cümledeki "halinden memnun olmak" ifadesi, tatmin olmak biçiminde alındığında, istemenin sınırlarının olmadığı bir diyara varıır. Meselenin konumuzla ve liberalizmle ilgili boyutu da budur. 
Filmde de daha aşağı seviyede olanlar aç kalma tehdidiyle karşı karşıyadırlar. Ancak her bir mahkûm ancak daha yukarı bir seviyede olursa daha çok yiyeceğe ulaşabilir. Aynı şekilde, her mahkûm kendisini yukarı seviyedekilerle değil, aşağı seviyedekilerle karşılaştırır. Çünkü büyüklük hissi her zaman yukarıdan gelir. Aynı nedenledir ki, her mahkûm kendisinden aşağı seviyede bulunanlar üzerinde buyurgan tutum ve davranışlar sergileyebilirken; yukarıdakilere itaat etmek zorundadır. Çünkü kötülük de yukarıdan gelir. Bu noktada, Goreng karakterinin alt kattakileri kendilerine ayrılan porsiyonları yiyip onları platformun üzerindeki diğer yiyeceklere dokunmamaya mecbur etmesi ${ }^{3}$ üzerine Imoguiri ile arasında geçen şu diyalog oldukça açıklayıcı niteliktedir:

Imoguiri: "Bakalım yukarıdakileri ikna edebilecek miyiz?"

Goreng: "Hayır. Yukarıdakiler beni dinlemez."

Imoguiri: "Neden?"

Goreng: "Çünkü yukarı doğru s*çamam hanımefendi" (48:34-48:43).

Goreng, amiyane ifadesiyle, "yukarıdakilerin" alim-i mutlak konumunu mükemmelen tesciller gibidir. Öte yandan, bu kısa diyalog hiyerarşinin alt-üst ilişkisi ve/veya karşılaştırmasını olumlayıp meşrulaştırdığı gibi, kültürel çevre içindeki davranış normlarının şekillendiği habitat bağlamında da statüyü olumlar. Ayrıca aşağıda olanın yukarıdakine tabiiyeti, 333 kat boyunca silsileli biçimde bir güç-denetim zinciri ilişkisi yaratır. Platformun üst seviyeleri, hissedilen bütün cismanî disipline ve katı gözetime karşın yine de çekicidir. Zira üst seviyelerdeki habitat, asıl panoptik gücün kendi ayrıcalığı olan denetleme yetkisinin bir bölümünü -kısmen ve geçici de olsa- tutsaklara bahşetmiştir. Pek tabii ki, iktidarın platformun yukarı katlarındaki tutuklulara lütfettiği bu egemenlik kırıntısının geçerlilik alanı yalnızca alt seviyelerdir. Burada önemli olan şey, basit bir yetki devri değildir sadece, mahkûmlara tanınan bu lütufla birlikte gözetim sisteminin maliyetten ari olması, denetimi gitgide mahkûmların içinde işleyen bir düzeneğe dönüştürmesidir. Klasik deyimle söylersek, artık herkes önce kendisinin, sonra birbirinin gardiyanıdır. Böylece, panoptik formda tasarlanmış yapı neredeyse sıfır maliyetle kendisine itaat eden ve rıza gösteren bireyler yaratır. Mahkûmların istisnasız tümü gözetim mekanizmasına koşulsuz itaat ederken, aynı zamanda sistemin birer taşıyıcısına dönüşürler. Mahkûmların hayatta kalma çabası ile üst seviyeye çıkma umudu düzenin işlevselliğine katkı sağlar.

3 Goreng, filmin bir yerinde alt seviyedekileri yiyeceklerin üzerine dışkısını yapmayla tehdit edip onları itaata mecbur bırakır. 
Görsel 3: Tatlıdan çıkan kıl ve şefin öfkesi

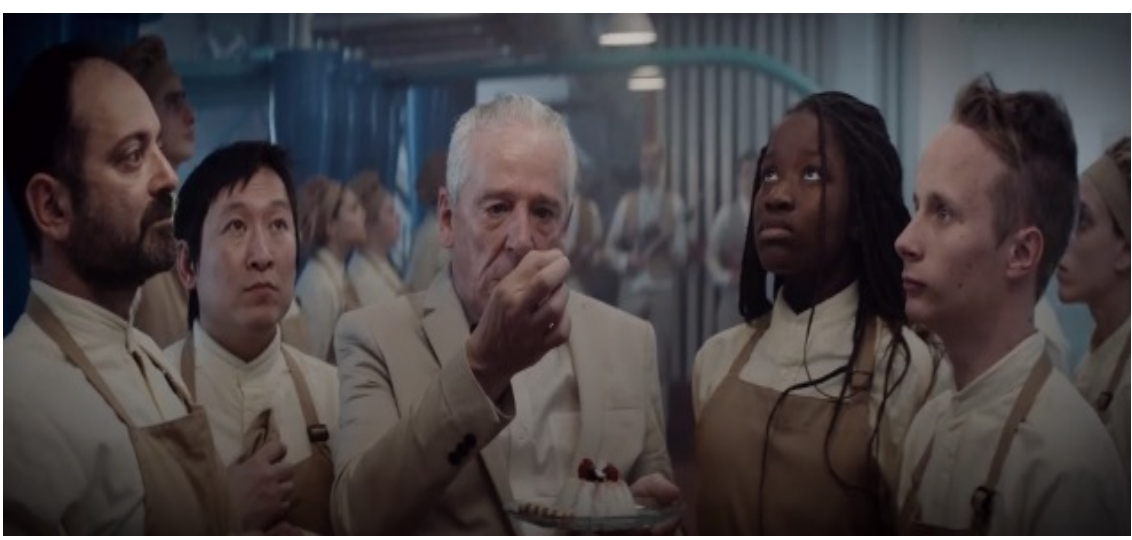

\section{Görsel 3'ün Çözümlenmesi}

Gösterge: Şef, mutfakta çalışanlara tatlıdan çıkan kılı göstermektedir. Gösteren: Hizaya geçmiş çalışanlar, şef, tatlı tabağı ve şefin elindeki kIl

\section{Gösterilen}

Düz anlam: Şef, mutfak çalışanlarını tatlıdan kıl çıktığı için azarlamaktadır. Zira yemeklerin içinde herhangi bir yabancı madde bulunması makul karşılanan bir durum değildir.

Yan Anlam: Tatıdan kıl çıkması hasebiyle çalışanların şefin öfkesiyle hazırola geçmeleri, sistemin hem -görünüşte- mükemmelliyetçi hem de normatif yönünü simgeler. Sistem mükemmeldir; zira üretilen şiddet ve eşitsizlik ancak abartıı bir uyum ve mükemmellik söylemiyle bertaraf edilebilir. Normatiftir; zira kendini her türlü sapmadan ari biçimde konumlamış bir sistem için uyum ancak kuralların titizlikle tatbikiyle mümkündür. Öte yandan, filmde bariz biçimde vurgulanma gereği duyulan hijyen saplantısı da sistemin kendini "aklama" gerekçeleri açısından hayati bir öneme sahiptir; nezaket, nefaset, görgü, saygı gibi kavramlar arkasına gizlenmiş barbarlık, en açık biçimde paylaşım savaşında ortaya çıkar. Dolayısıyla, gerçekte neoliberal sistemin bu disturunun altında açlıktan kıvranan insanlar vardır ve bir anlamda medeniyeti lafzen bile temsil eden kavramlar filmde korkunç bir ironi yaratır. Bu ironik bakış, açlıktan her şeyi talan edecek kadar gözü dönmüş, vicdanen ve ahlaken büyük sapmalar yaşayan "modern" insanın fikren çöküşünün göstergesi gibidir. Özetle, bu göstergenin içerdiği yan anlam, sistemin kusursuzluğa ve değerlere yönelik uygar yaklaşımı ve savunusu ile pratikte kendi 
mamülü olan bireylerde yarattığı değer zayiatı arasındaki çelişkide gizlidir. Söz konusu paradoks, neoliberalizmin bütün olumlu gibi duran iddialarına (özgürlük, özerklik, yetkinlik, vb.) rağmen modern bireyin en temel fizyolojik intiyaçlarını karşılayamaması sonucu yaşadığı değer kaybında somutlaşmaktadır.

Fiziksel hareket alanları kısıtlı olan bedenlerin tutulduğu dikey hapishanede, mutfak hiyerarşinin başlangıç noktasıdır. Mutfakta ihtimamla hazırlanan ve servis edilen yemekler -yaşanacak- çatışma ve -alınacak- rızanın temelini oluşturur. Yemeklerin böylesi bir özenle hazırlanıp sunulmasındaki asıl ironi ise, kusursuzluk söyleminin platform henüz birinci seviyeye ulaşır ulaşmaz bozulmasıdır. Toplumsalın içinde ekonomik, siyasi ya da benzer ölçütler aracılığıyla tabakalara ayrılan bireyler ve onların oluşturdukları cemaatler yalnızca dünya görüşlerini değil, aynı zamanda ekonomik kaynakların bölüşümünü de şekillendirir. Söz konusu bölüşüm adaletsiz ve vahşi bir görünüm aldığındaysa, tüm insanları düzene ve yasalara uymaya davet etmekten başka çıkar yol yoktur. Filmde tabakaların ve/ veya platformun üst seviyesinde bulunanlar kaynakların eşitsiz bölüşümüne neden olup sosyal tabakalaşmanın sınırlarını daha da belirginleştirirler. Dolayısıyla, kusursuzca işleyen düzeneğin kusurlu bireyleri yola getirecek sertlikte ve caydrıcı çözümler üretmesi de kaçınılmazdır. Görsel 3'te, şefin tatıdan çıkan kılı bürokratik bir öfkeyle karşılaması ve çalışanları paylaması, söz konusu mütehakkim tavra örnektir. Tavrın katılığı, bir yerde disiplinin işlevselliğinin kanıtıdır. Gelgelelim, tabaktaki kıla gösterilen abartılı ve hoşnutsuz tepki, sistemin ürettiği cürufu gizleyeceğim derken daha da açık etmektedir. Çünkü mahkûmlar, platform alt katlara doğru indiğinde, artık yemeğin huzurunda değil, tüm cüsseleriyle onun içindedirler!

Görsel 4: Ortam ısısının ani ve aşırı değişmesi

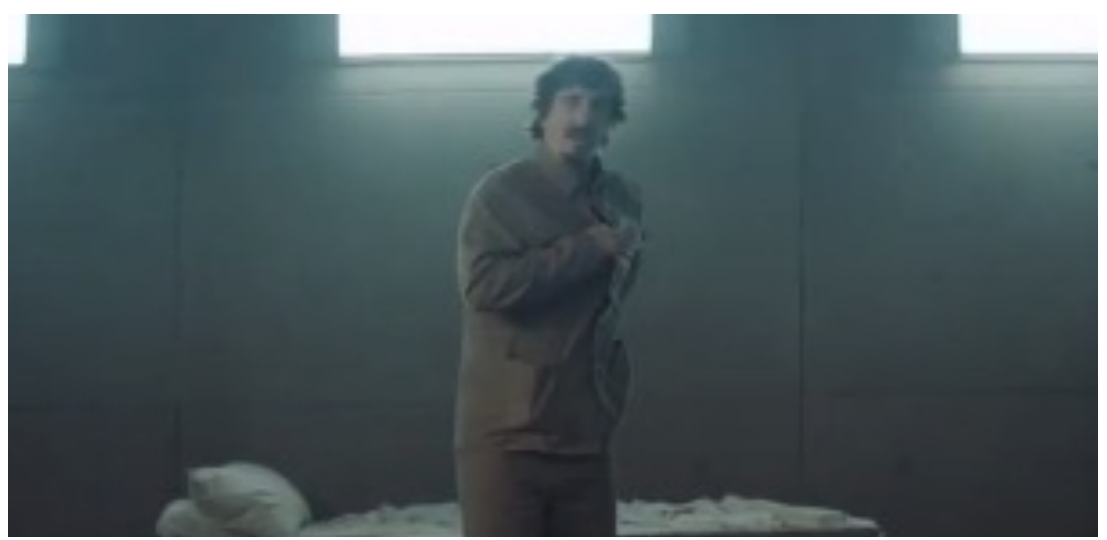




\section{Görsel 4'ün Çözümlenmesi}

Gösterge: Dağınık bir yatağın önünde ayakta duran bir erkek.

Gösteren: Goreng

Gösterilen

Düz anlam: Goreng karakterinin platform bir alt seviyeye inmesine karşın bir elmayı yanında tutması sonucu ortam ani bir şekilde ısınmaya başlar.

Yan Anlam: Panoptik denetimin halihazırda bütünü gözetleme ve disipline etme mirasını dijital, süperpanoptik bir denetim mekanizmasına devrettiği tartışılsa da, bu sahnede sistemin alimimutlaklığı tartışmasızdır. Görülmeden gören gözün etkinliği -Goreng'in cebi dahil!- her yerdedir. Sahne, bu açıdan söz konusu tartışmayı insanlığın ortak teknolojik hafızasının biriktirdiklerinin gözetim kulelerini görünmez kıldığı varsayımıyla destekler niteliktedir. Vücut ısısını ölçmek suretiyle denetim sağlayan teknikler burada hapishanenin klimatik evrenine taşınmıştır. Yanı sıra, bu gösterge, neoliberalizmin biyopolitik denetim düzeneğinin nesneleleştirdiği ve nezaret ettiği bedenlere gizlenmeyi, gözden kaybolmayı men eden kuşatıcıığına da karşılık gelmektedir. Bu bağlamda sistemin modern insana her koşulda yöneltebileceği suçlayıcı üslubu da görünür olmaktadır. Çünkü -panoptik veya biyopolitik- gözetim, salt görsel nitelikli olmanın ötesinde, aynı zamanda ve her şeyden önce birey hakkında bilinen bilgiyi temel alır: Elma, el çabukluğuyla Goreng'in cebini boylamıştır, ancak kamera her şeyi kaydetmektedir, vs. Dolayısıyla nezaret altında tutulanlar hemen her saniye "görünürlüğün tuzak" olduğu bir kıstırılmışlığı yaşarlar. Öte yandan, iktidar norm ve yasa koyucu sıfatıyla bedenleri caydırıcı yaptırımlarla nizama soktuğundan, mahkûmların her dakika başkalarının bilmediğini bilen bir gücün tedrisinden geçtiklerinin farkında olmaları, cezalandırmadan muafiyet açısından onların yararınadır. Zaten panoptik denetimin ilk hedefi de cezalandırma değil, caydırmadır.

Filmde herhangi bir seviyede verilen süre dışında yeme-içme eylemi tamamen yasaktır. Bu durum mahkûmların yemek yeme biçiminin ve süresinin bütünüyle iktidarın kontrolünde olduğunu gösterir. Ancak sistem yine de kimi açılardan ciddi defolar üretebilmektedir: Rutin yeme düzeninin vahşi ritmine zaman zaman konan kurallara uymayanların, her an yasakları ihlal etme düşüncesinde olanların bahtsız çabaları eklenir. Sistem, kendi kaçağını kendi önleyecek önlemlere de sahiptir öte yandan. Buna göre, şayet platform bir aşağı seviyeye indiğinde üst katlarda hâlâ yiyecek bir şeyler varsa veya kalmışsa, ortamın ısısı ani bir şekilde değişmektedir. Nitekim filmde bu durumun gerçekleştiği olaylardan 
birinde, Goreng'in platform aşağı kata inmeden önce yiyeceklerin içinden bir elma (ç)almasıyla ortam ani bir şekilde ısınmaya başlar. Bu bağlamda aşağıdaki diyalog iktidarın bilgiyle disiplini kaynaştımasına somut bir örnek oluşturur:

Trimagasi: "Sizin suçunuz... Isı giderek yükselmeye devam edecek tabii siz..."

Goreng: "Tabii ben... Ne?"

Trimagasi: "O elmayı atmadığınız sürece... Yiyecekler platform bizimle aynı seviyede olduğunda bize aittir. Eğer yiyeceği saklarsanız sıcaklık biz burada yanıncaya kadar devam edecek ya da donuncaya kadar azalacak, belli olmaz" (08:59-09:21).

Diyalogdan da anlaşılacağı üzere, gözetleme bireyin en temel intiyacı olan beslenme eyleminin kontrolüyle gerçekleşir. Elbette böylesi bir gözetimin günümüzün neoliberal dünya düzeninde kapitalizmin bencilce değerlerine koşut gelişen bir durum olduğu söylenebilir. Filmde, panoptik iktidar mekanizması, yasakladığı ya da onaylamadığı davranışı engellemek için yalnızca mahkûmların vücut ısılarına değil, aynı zamanda bencilce arzularına ve içgüdülerine varıncaya dek onları denetlemektedir. Hatta söz konusu denetim bazı mahkûmlar tarafından öylesine normalleştirilmiş ve içselleştirilmiştir ki, sözgelimi filmdeki Trimagasi karakterinin, çoğu ikaz edici nitelikteki konuşmalarından, içinde bulunduğu sistemi ve onun sinsice işleyişini özümsediği ve kabul ettiği görülür. Ayrıca iktidarın dijital kontrol mekanizması adeta otomatik bir refleks üretir. Yiyeceklerin ancak platform mahkûmların bulunduğu seviyedeyken onlara ait olduğu kuralı, gündelik hayatta çiftliklerde tutulan hayvanlar için de geçerlidir: Önlerine konan yemi belirlenen sürede yemek zorundadılar. Düzenden çalan ve kaçak avlananlar, sınırlı imkânlara mahkûm edilerek cezalandırııılar. Dolayısıyla panoptik denetim düzeneği nesneleleştirdiği ve nezaret ettiği bedenler arasında keskin bir ayrım yapabilme özelliğine sahip değildir. Özetle, muktedirin bilgisine sahip olduğu her ihlâl, failin koşullarını daha da zorlaştııır.

Görsel 5: Açlığın çukurunda, insan oluşun sınırında

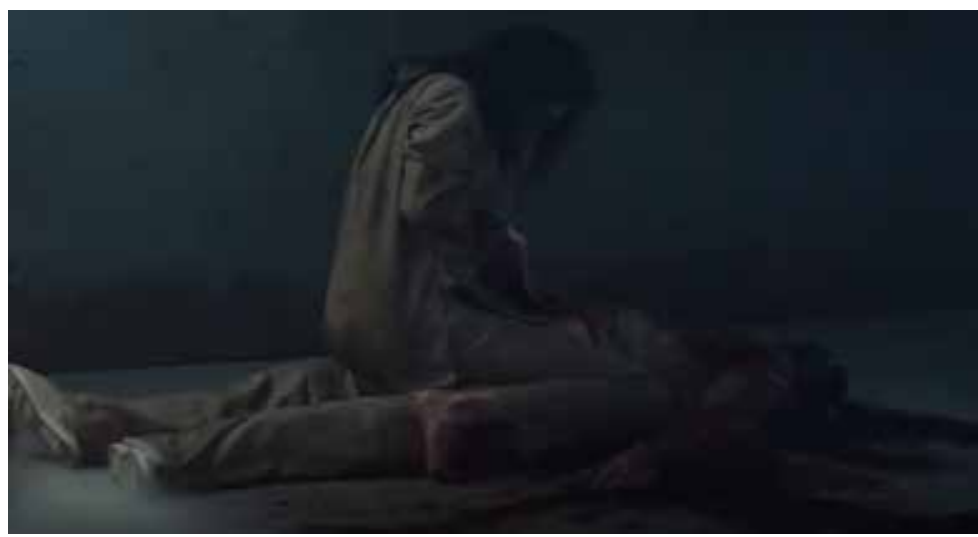




\section{Görsel 5'in Çözümlenmesi}

Gösterge: Kanlı bir ortam, cesedin üstünde oturan bir kadın.

Gösteren: Bir kadın cesetten et parçaları koparmaktadır.

Gösterilen

Düz anlam: Kadın hayatta kalmak için, cesetten parçalar koparmaktadır. Zira platformun üzerindeki yiyecekler kadının bulunduğu seviyeye gelene dek bitmektedir.

Yan Anlam: Bu kare, adeta modern insanın ilkel benliğinin fotoğrafı gibidir. Bireyin elzem ihtiyacı olan beslenme eyleminin olağan rotasından sapması uygarlığın insanlığa vadettiği olanakların yıkımıyla sonuçlanır. Böylece uygarlık merdivenini hızla gerisin geri inen insan, kendini bambaşka bir zihin evreninin karanlığında bulur. Sistem içindeki böylesi bir yıkım sapkın ve yabani eylemlerin de adeta habercisi niteliğindedir. Bu bağlamda, olaylar adeta bir "survivor" ambiyansına dönüşüp, yaşamak için öldürmeye mecbur kılınan birey için yamyamlaşmak kaçınılmaz olur. "Kazanan hepsini alır" ekonomisinin kusursuz bir prototipi görünümündeki survivor türü programlarda da kazanmak ve büyük ödülü "kapabilmek" için rakiplerini hasım yerine koyup yetilerine gayrı ahlaki çelmeler takan barbar bir anlayış vardır. Her halükârda, yegâne insani vasıfların müsamahasız bir gücün kontrolünde erozyona uğraması, insan tabiatının derinliklerindeki ilkelliği görünür kılar. Platformun sunduğu harikulade yemek sofrası sistemin niş noktalarını kapatıp kusursuz bir tablo çizmekle kalmaz, aynı zamada söz konusu tablo arka planında açııtan yamyamlaşmanın vahşi normunu inşa eder. Kısacası bu göstergenin içerdiği yan anlam, neoliberalizmin toplumsal/kültürel hayatta bulduğu hareket alanının, sistemin tüm yapıcı öğütlerine karşın, bireyi en temel ihtiyaçların karşılanması konusunda amansız bir mücadeleye, insan oluşun sınırına sürüklediğidir.

Açlığın ve mutlak çaresizliklerin başladığı yerde, gitgide insan oluşun asgari zeminine varılır. İnsan, adeta kendi doyurulmamış arzuları içinde çukurlaşmış bir varlığa dönüşür. Özellikle telafisi mümkün olmayan eşitsizliklerden malul toplumlarda alt sınıfların çaresizliği ve umutsuzluğu orta ve üst sınıflara doğru gidildikçe perişan manzaraların görece daha düşük olduğu bir duruma evrilir, vb. Filmde de, daha başlangıçtan bu görüşü fiiliyatta teyit edecek bir dizi mizansen göze çarpar. Ancak farklı seviyedeki mahkûmlar üzerinden görünür kılınmaya çaIışılan bu sınıfsal temsil, gerçek yaşamda şu gerçeği de gözlerden gizlemeyi başaramamaz: Kimilerinin "vahşi alt sınıf" dediği toplumsal katmanların çaresizlik sonucu yöneldiği kimi sapkın eylemler, "aslında günümüzün vahşi seçkinlerinin aynadaki yansımasından ibarettir" (Bauman, 2020, s.93). Başka bir deyişle, alt- 
takilerin sergilediği vahşet, onları üsttekilerle eşitlemektedir. Zira filmde de üst seviyelerde ikamet edenlerle alttakilerin isyan potansiyeli ve irrasyonel hareket etme yatkınlığı arasında pek fazla bir fark yok gibidir: Alttakiler birbirlerini yerler, üsttekilerse yemeğe pislerler. Platformun aşağı seviyelerine inildikçe bireyleri bir eyleme ikna etmenin daha da güçleşmesi ise, olsa olsa mutlak yoksunluğun ve sefaletten kendi durumu üzerine bir türlü düşünememenin farklı bir boyutunu oluşturur. Aynı insan dışı koşulların baskın çıkışı yüzündendir ki, filmin en vurucu mesajlarından birisinin, kontrol altında tutulan mahkûmların örgütlenmesinin imkânsızığı olduğu söylenebilir. Zira akılcı bir iktidara karşı mücadele etmek için zihinsel yaratıcıı̆ı̆ doruklarında zekice planlar yapmak gerekir. Bu da, öncelikle kimi temel ihtiyaçları açığa vuran dürtülerin doyurulmasına bağlıdır.

\section{Sonuç}

Insanı, kendi toplumsal ve maddi koşulları içinde yakalamayı, anlamayı ve göstermeyi amaçlayan filmlerin beyaz perdeye taşıdığı dünya izleyiciye farklı hikâyeler sunar. Aynı şekilde, bir filmi sosyolojik açıdan incelemekle de o filmin üretildiği toplumun çok farklı kesitlerine ışık tutulmuş olur. En azından böylelikle, “(...) filmin yaşamdan neler aldığını ve yaşama neler kattığını görebilmek, yönetmenin farkında olmadan işlettiği bilinçaltı süreçlerini yorumlayabilmek, kurulan dil oyunlarının ayırdına varabilmek ve ideolojileri çıkarsayabilmek; en azından bunları tartışabilmek olasıdır" (Öztürk, 2000, s.15). The Platform filminde de hedeflenen şey, özünde budur. Zira bir film üretildiği dönemin tarihsel, toplumsal, kültürel ya da teknolojik koşullarından etkilenmekte ve böylece ideolojik ve sosyal anlamların da taşıyıcısı olmaktadır. The Platform filmi, bu anlamda, neoliberal toplumsal sistemin eşitsizlikçi evreninde ve gözetimci pratiklerle biçimlendirilmiş bireyi üzerinden bir dizi değer, motif ve ideolojiyi tartışmaya açmaktadır. Bu bağlamda, türlü yaptırımlarla özgürlügüne sınırlamalar getirilmiş bireyin, adeta bir doğa düzenini andıran sistem içinde hayatta kalma çabası ve zihinsel algısındaki olumsuzluklar The Platform filminin ortaya çıkmasına kaynaklık eden en temel endişelerdendir. Bu endişe, filmin distopik yönünü açığa vurduğu gibi, söz konusu kurgusal evrenin gözetimci yönüne de ışık tutmaktadır. Bununla birlikte, aynı distopik niteliğinden dolayı, filmin zamanının ötesinde bir anlatı biçimini temsil ettiği söylenebilirse de, bizatihi bir ürünü olduğu tarihsel, sosyal, ekonomik ve teknolojik bağlam göz önüne alındığında, gözetimci pratiklerle de tahkim edilmiş olarak, yürürlükteki neoliberal yaşam formunun modern bireyde yarattığı ve yaratacağı tahribata odaklanıldığı görülmektedir. Yanı sıra, filmde alt-üst hiyerarşisi tüketim ürünlerine erişimden referansla panoptik denetime tabi olan mahkûmlar arasında farklı "yaşam şansları" yaratmaktadır ki, bu sonuncu durum da herkesin aynı yaşamsal koşullara sahip olmadığını ve/veya olamayacağını vazeden neoliberalizmin dolaysız yansımalarından birisidir. Dahası, film söz konusu eşitsizliğin sosyolojik ve psikolojik manzaralarını yer yer nekro-politik bir seviyeye varan biyopolitik denetim düzeneğiyle birlikte, kapitalizmin özsömürüyü de içeren çarpık tüketim alışkanlıkları, müsriflik ve iktidarın kolonları gibi konulara gönderme yapan kimi güçlü sembol ve metaforlarla sunmaktadır. Filmde kaynaklara erişim de sahip olunan 
konumla -aşağıda veya yukarıda olmakla- doğrudan ilişkilidir. Aşağıda olanlar konumları itibariyle ancak yukarıdakilerin tüket(e)mediği kaynakların artıklarıyla idare etmek zorundadırlar. Üsttekilerse, her koşulda müsrifçe bir konforun tadını çıkarmaktadırlar. Bu karanlık manzara neoliberal kapitalist düzenin ihtiva ettiği sömürüye koşut biçimde sunulan bir gündelik yaşam görüntüsüdür. Geleceğe yönelik bir temenni olarak, gözetim ve düzen eleştirisini sosyolojik film analiz türünün yanı sıra, daha metaforik ve sembolik bir perspektifle odağına alan The Platform ve benzeri distopik film türlerinin arketipal nitelikli bir eleştirisi de pekâlâ yapılabilir.

\section{Kaynakça}

Akbulut, H. (2010). Film Çözümlemeleri. Erişim 10.11.2021, http://auzefkitap.istanbul.edu.tr/kitap/radyotelevizyonsinema_ue/filmcozumlemeleri.pdf

Althusser, Louis (2000). İdeoloji ve Devletin İdeolojik Aygıtları. (Yusuf Alp-Mahmut Özışık, Çev.). İstanbul: İletişim Yayınları.

Aumont, J. 2005. Matière d'images. Paris: Éd. Images Modernes.

Avcı, Ö. (2015). Dijital Yaşamın Dijital Özne(l)leri: Herkes ya da Hiç Kimse. Uşak Üniversitesi Sosyal Bilimler Dergisi. (8) 1, 249-266.

Barthes R. (1993). Göstergebilimsel Serüven. (Mehmet Rifat-Sema Rifat, Çev.). İstanbul: Yapı Kredi Yayınları.

Bauman, Z. (2001). Parçalanmış Hayat. (I. Türkmen, Çev.). İstanbul: Ayrıntı Yayınları.

Bauman, Z. ve Lyon, D. (2013). Akışkan Gözetim. (E. Yılmaz, Çev.). İstanbul: Ayrıntı Yayınları.

Bauman, Z. (2020). Eğitim Üzerine. (Akın Emre Pilgir, Çev.). İstanbul: Ayrıntı Yayınları. Bourdieu, P. (2006). Karşı Ateşler. (Halime Yücel, Çev.). İstanbul: Yapı Kredi Yayınları. Çetin, V. (2020). Bong'un Treninden Vincenzo'nun Küp'üne The Platform'a Bir Bakış. Erişim 12 Mayıs 2021, https://www.gazeteduvar.com.tr.

Diken Yücel, D. (2015). Sinema Filmlerinde Gözetim ve İktidar Illişkilerinin İnşası. International Journal of Social Sciences and Education Research, 1 (2), 390-398.

Erbaş, Ş. (2015). Eşik Burcu: Bütün Yazılar-3. İstanbul: Kırmızı Kedi Yayınları.

Foucault, M. (2006). Hapishanenin Doğuşu. (M. A. Kılıçbay, Çev.). Ankara: Imge Kitabevi.

Foucault, M. (2019). İktidarın Gözü. (I. Ergüden ve O. Akınhay, Çev.). İstanbul: Ayrıntı Yayınları.

Han, B.-C. (2019). Psikopolitika: Neoliberalizm ve Yeni Iktidar Teknikleri. (Haluk Barışcan, Çev.). İstanbul: Metis Yayınları.

Hobbes, T. (2014). Leviathan. (Semih Lim, Çev.). İstanbul: Yapı Kredi Yayınları. 
Kabadayı, L. (2013). Film Eleştirisi Kuramsal Çerçeve ve Sinemamızdan Örnek Çözümlemeler. İstanbul: Ayrıntı Yayınları.

Kozanoğlu, H., Gür, N., Özden, B. A. (2008). Neoliberalizmin Gerçek 100'ü. İstanbul: Illetişim Yayınları.

Lacombe, D. (1993). Les liaisons dangereuses: Foucault et la criminologie. Criminologie. (26)1, 51-72.

Lyon, D. (2006). Günlük Hayatı Kontrol Etmek Gözetlenen Toplum. (G. Soykan, Çev.). İstanbul: Kalkedon Yayıncılık.

Mbembe, A. (2003). Necropolitics. Public Culture, 15(1), 11-40.

Medin, B. (2019). Film Anlatısında Kahramanın Değişen Özne Konumu: Başkalarının Hayatı Filmi Örneği. Erciyes İletişim Dergisi, 6 (1), 149-168.

Merlin, M. (2009). Foucault, le pouvoir et le problème du corps social. Erişim 15 Haziran 2021, https://www.cairn.info/revue-idees-economiques-et-sociales-2009-1-page-51.htm

Metaforlarla Dolu Etkileyici Netflix Filmi The Platform'un İncelemesi. Erişim 23 Mart 2021, https://seyler.eksisozluk.com.

Mill, J. S. (2017). Faydacılık. (Gökhan Murteza, Çev.). İstanbul: Pinhan Yayıncılık. Öztürk, S. R. (2000). Sinemada Kadın Olmak. İstanbul: Alan Yayıncılık.

Peirce, C. (1982). Writings of Charles S. Pierce. Bloomington: Indiana University Press.

Scheurmann, E. (2016). Göğü Delen Adam. (Levent Tayla, Çev.). İstanbul: Ayrıntı Yayınları.

Sucu, I. (2020). Gözetlenen Toplumun Gözetleyen Topluma Dönüşmesi: "The Truman Show Filmi" Örneği. Aksaray Illetişim Dergisi, 2 (1), 1-12.

The Platform'un Yönetmeni Gaztelu-Urrutia: Bu, Toplumsal Bir Öz Eleştiri Filmi. Erişim 12 Nisan 2021, https://www.cumhuriyet.com.tr/haber/the-platformun-yonetmeni-gaztelu-urrutia-bu-toplumsal-bir-oz-elestiri-filmi-1732619

Yalçınkaya, S. E. (2020). The Platform -El Hoyo-Delik-Filmi Üzerine. Erişim 26 Nisan 2021, https://sendika.org/2020/04/the-platform-el-hoyo-delik-filmi-uzerine-585324/ 


\section{Filmin Künyesi}

Yönetmen: Galder Gaztelu-Urrutia

Yapım yılı ve yeri: 2019, İspanya

Senarist: David Desola, Pedro Rivero

Süre: 94 dakika

Oyuncular: Iván Massagué, Antonia San Juan, Zorion Eguileor, Emilio Buale Coka, Alexandra Masangkay 